\title{
EARLY DAYS IN WESTMORELAND STREET
}

\section{BY ROBERT MARSHALL}

It may be of interest to you if I give you an account of what the Heart Hospital was like almost 50 years ago. This is necessarily a very personal narrative, and I fear that the personal pronoun will appear too often. It is in happy retrospect the impression I formed when I had the great good fortune to be the first resident medical officer in the National Hospital for Diseases of the Heart in what was then its new home in Westmoreland Street.

On December 17, 1913, I entered Soho Square, redolent in those days of the vinegar and spices of Crosse and Blackwell's factory. The hospital was tucked into the south-west corner of the square. It was a nice old house, designed by the brothers Adam (Fig. 1) for Sir Joseph Banks, who took part in the discovery of Australia with Captain Cook in the Endeavour (1768-71). There were 26 beds for in-patients and limited out-patient accommodation. The hospital was then about to move into its new home in Westmoreland Street, erected at a cost of $£ 21,000$.

I was on the short list for the appointment as first R.M.O. in this new building. My interview was timed for 5 o'clock, so I did a reconnaissance early in the afternoon. I was received by a blond and cheerful young man, one Robert Whitney, the hospital secretary, who shook me a little when he told me that I was "a dam smart fella". I at once agreed, and congratulated him on having noticed that so quickly. He then produced from a drawer in his desk my letter of application, held it up and said, "Why did you do that?" Then I was nonplussed, and said, "Do what?" "Why did you

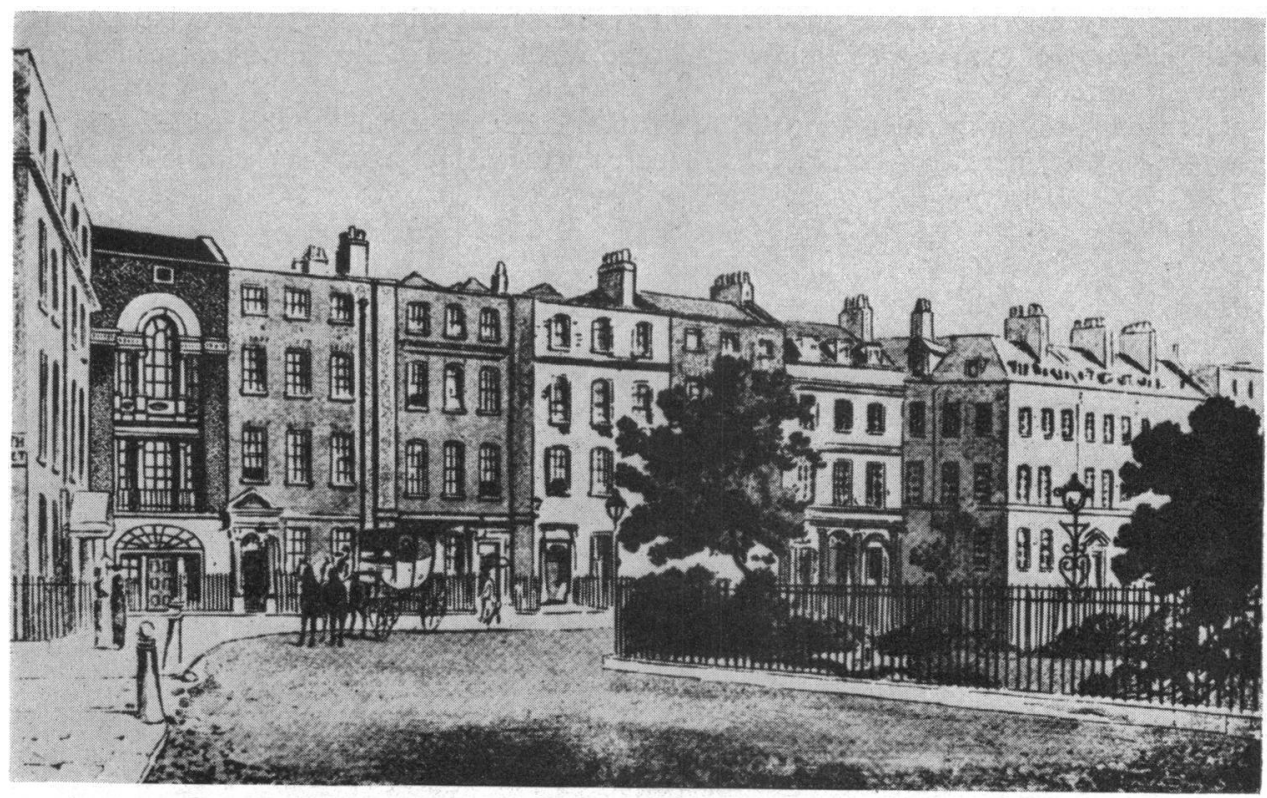

FIG. 1.-Soho Square, in the corner between Oxford Street and Charing Cross Road. No. 32, the home of the National Hospital for Diseases of the Heart from 1874 to 1914, is shown in the lefthand corner. The house was built by the Adam brothers for Sir Joseph Banks, President of the Royal Society 1778-1820, and was later the home of the Linnaean Society. 
put that in a registered envelope?" I replied that it was to impress on this institution the extreme importance of the documents it contained. He said, "Do you know, I believe that is going to get you the job. It has taken you out of the ruck. I show this to members of the staff and say, Belfast business methods: an Ulsterman spends his tuppence." Ever since then I have advised applicants for a post to register their applications, though now it costs more than tuppence. To my surprise and delight I was selected by the Medical Staff. My appointment was ratified by the Board the following afternoon. Whitney took me to the Cafe Royal for a drink to celebrate my selection. When he ordered absinthe for himself I thought that the ground would open and that Beelzebub would stretch up a fiery arm to snatch him down, and I knew that I was going to spill my lemonade.

The Chairman of the Board was an interesting man: Sir James Harrison, K.C.V.O. (Chairman, 1913-1921). He had been Clerk to the Privy Council for many years, and almost worshipped the memory of King Edward VII. He was supposed to be rather tough, but when he mentioned King Edward his eyes filled with tears. He regarded King George as a poor substitute, and did not live to realise that 25 years later King George $V$ would have achieved a place in the hearts of his people even more firmly than his brilliant father. Before crossing to London again to take up my duties on January 1, 1914, I received a telegram from Whitney: "Have accepted dinner invitation for you Tuesday evening. Please confirm." I did so and found that Dr. Sydney Russell Wells had arranged a special dinner-party in his own house in Seymour Street to welcome me to London. How many of us have ever given a special dinner-party, complete with tails and white ties, to welcome a new, raw house physician? Little did I think that, 43 years later, I would be a guest of the hospital at its Centenary Dinner, when Robert Whitney received a presentation in recognition of his long and faithful service.

Westmoreland Street Hospital was still empty, but I was given a pleasant suite of rooms. My salary was $£ 80$ per annum, $£ 60$ more than as a houseman in Belfast. I felt that $I$ had never had it so good. Our 40 beds rapidly filled, and soon 7 out-patient sessions, 5 afternoons and 2 evenings weekly, were in full swing. I was the only resident, and there were no registrars. I wrote up the case notes of 40 in-patients, assisted in all 7 of the outpatient sessions, and did all the electrocardiograms, including their processing in the tiny dark-room off the room where the cardiograph was housed. (John Shepley Part did his X-ray pictures in another little room.) The electrocardiograph was, of course, the Standard Cambridge model of the period (Fig. 2). The source of light was a spluttering carbon arc lamp, which required a sharp tap at the last moment to ensure maximum brightness. The electrocardiograph in its basement room could be

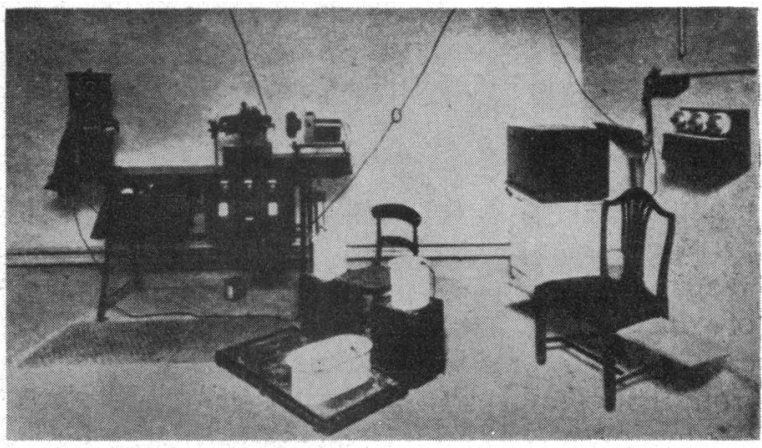

FIG. 2.-The original electrocardiographic room at the National Hospital for Diseases of the Heart in 1914, showing an early Cambridge electrocardiograph that was still in use till 1949; and many parts of it have been incorporated in another apparatus still in use. connected by 3-lead cable to each bed in the wards upstairs, with a portable telephone, but this did not prove a satisfactory method. My time was fully occupied, so I had little chance of taking busmen's holidays, but I did get across to the London Hospital one afternoon to make the acquaintance of a young man of growing reputation. His name was John Parkinson.

The hospital had two consulting physicians of great distinction. One was Dr. Frederick Taylor, soon to be Sir Frederick Taylor, Bart., P.R.C.P. He had been our external examiner in medicine in Queen's, and was certainly the most terrifying examiner I have ever encountered. He came to see us occasionally, benign and friendly, except when we showed him a patient with a mediastinal tumour 
and he insisted that it was an aortic aneurysm, expressing his contempt for X-rays and the Wassermann test in no uncertain manner; so we changed the subject.

The other was not a practising physician, but a famous physiologist, none other than Augustus Désiré Waller, the man who had recorded the first human electrocardiogram in 1887 and written a

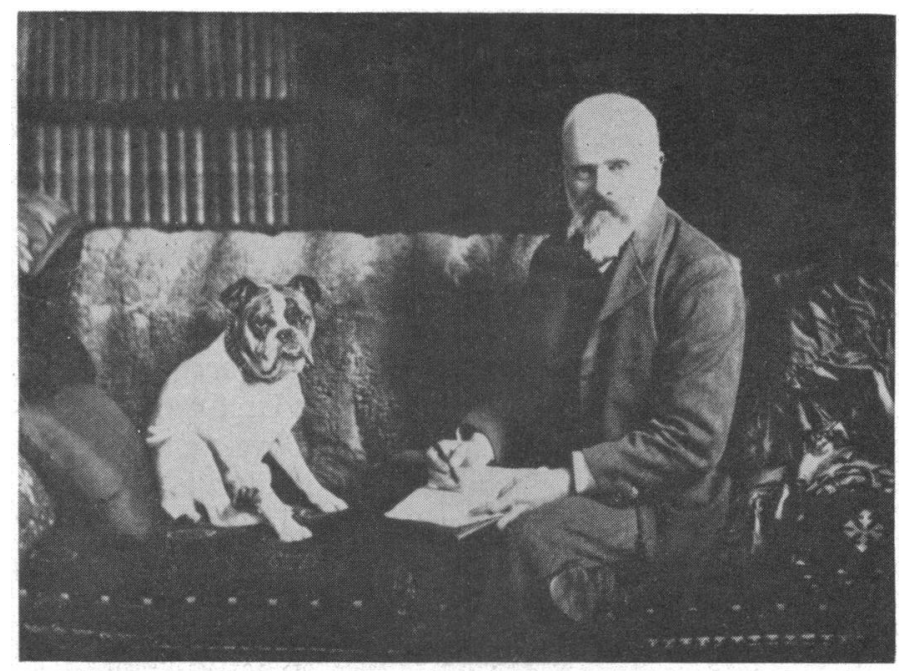

Fig. 3.-Augustus D. Waller, F.R.S., Professor of Physiology, London University, Consulting Physician to the National Hospital for Diseases of the Heart, with his bulldog, Jimmy. In 1887 he had obtained the first record of the electrical action of the heart, and his bulldog was the subject of many of his observations.

monumental paper on the subject. He was the son of Augustus V. Waller, whose name is perpetuated in the "Law of Wallerian Degeneration." Sydney Russell Wells used to recall how Waller had told one of his lab. boys to bring him two jampots full of salt solution, into each of which he had inserted one of the boy's hands, and a zinc electrode which he led to a Lippmann's capillary electrometer, and thus got his first records. Waller presented a very different appearance from that of our physicians, who were always soberly garbed in frock coats or morning coats and silk hats. He was a short, stocky man, very light on his feet. His grey beard and double-breasted blue jacket made him look exactly like a skipper in the Merchant Navy (Fig. 3). Like Sir Winston, he seemed to be habitually smoking cigars, and was invariably followed by his bulldog, Jimmie, who also had a Churchillian quality, and had the distinction of having had a question asked about him in the House of Commons, recorded as follows in Hansard.

Q. "At a conversazione of the Royal Society at Burlington House on May 12th last a bulldog was cruelly treated when a leather strap with sharp nails was secured around his neck and his feet were immersed in glass jars containing salts in solution, and the jars in turn were connected with wires to galvanometers. Such a cruel procedure should surely be dealt with under the 'Cruelty to Animals' Act of 1876.

A. The dog in question wore a leather collar ornamented with brass studs, and he was placed to stand in water to which some sodium chloride had been added, or in other words, common salt. If my honourable friend had ever paddled in the sea, he will appreciate fully the sensation obtained there by this simple pleasurable experience."

The silly question deserved its salty answer. 
When Waller came to the hospital he would dive into the basement, and I soon learned that within 15 minutes the electrocardiograph would be out of order, and off he would go, complete with bulldog, muttering about "these damned modern toys," and leaving behind an exquisite aroma of tobacco. One Sunday afternoon he invited us all to a tea-party in his house in St. John's Wood. The room was full, and I had the good fortune to be wedged in a corner with Thomas Lewis. I asked him whether right bundle-branch block was commoner than left, and he said the incidence was about 6 right bundle lesions to 1 left bundle lesion. I then asked him whether this was because the systemic circulation was more essential to life than the pulmonary, and he gravely agreed that this was a probable reason. Unfortunately for my theory, some years later the nomenclature of these lesions was reversed, and what we had regarded as right became left, and left, right.

There were five visiting honorary physicians on the staff, all very different, and I can give you only a thumbnail sketch of each. The senior physician was Charles William Chapman (1893-1914*), a Guy's man who qualified in 1867 and became an M.R.C.P. in 1890 . He had written papers on heart disease in childhood that gave a more modern and optimistic view than was usual. He was a quiet man with a rather engaging stammer. He used to say that "There is a g-g-great deal of t-t-truth in the old ad-adage, 'God sent wine and the devil sent spirits'." How right he was. He lived to be 97 . His outstanding quality was his kindness to his patients.

Robert Oswald Moon (1902-1930*) was a slender, elegant man with a pale face, dark eyes and a neatly-trimmed black beard. One scarcely needed to be told that he was an Oxford man. His gentle, almost deprecatory manner belied his adventurous spirit. He never talked about his exploits, but he had been a surgeon with the Phil-Hellenic Legion in the Graeco-Turkish war of 1897, and a civil surgeon in South Africa. Although no longer young, he served in the 1914/18 war. He was an ardent Liberal, a personal friend of Henry Herbert Asquith, and had been an unsuccessful candidate for Parliament. I often wondered why he invited me so frequently to his beautiful house in Montague Square, where we had wordy battles about Home Rule for Ireland, and I did not share his views. He was a Fellow of the College, and had written several papers on cardiology and on the history of medicine. He had a curious empirical faith in the therapeutic value of liqour ferri perchlor.

Sydney Russell Wells (1905-1924) also had a beard, but an aggressively red one. He was the pioneer of modern cardiology in the hospital. He had been demonstrator in physiology for Augustus Waller. He lost all sense of time when experimenting with his beloved electrocardiograph. One of the greatest days in his life was when Prince and Princess Arthur of Connaught performed the opening ceremony of the new building in January, 1914, and he demonstrated to them the wonders of this machine, with your humble servant sitting with hands and left foot in the little baths of salt solution as his stooge for the occasion. He afterwards became Vice-Chancellor of the University of London and a Member of Parliament, and was awarded a knighthood.

Many of you will remember Philip Hamill (1912-1923), who afterwards deserted cardiology for pharmacology. When I knew him first he was a big upstanding fellow in his early thirties, with quick, almost impatient speech, which still bore traces of the accent of his Ulster forebears. His devotion to his own teaching hospital was so deep that one felt that when he died one would find the word Bartholomew on his heart.

John Frederick Halls Dally (1910-1914) was a Cambridge man who seemed to find it difficult to believe that anyone coming from so remote a place as Belfast could know anything at all. He was very cosmopolitan, and had written many articles in French and German medical journals. His enthusiasm, especially for studies of variations in blood pressure, was unbounded.

Our pathologist was Kenneth Eckenstein (1910-1921), who was also addicted to writing scientific papers in French periodicals. We got relatively few occasions for doing necropsies, but I was always impressed with the fact that not only the pathologist, but the physician in charge of the patient, invariably came to see the morbid anatomy for himself.

* These dates are the period when they were members of the staff. Hamill and Halls Dally resigned early because of changing interests or other work. 
I have purposely left to the last of this brief resumé of the honorary staff the name of Cuthbert Chapman Gibbes (1897-1920). He became the senior physician during my tenure of office, and was one of the most remarkable people I have ever met. Like Waller, he had qualified originally in Aberdeen, although very much an Englishman. He became an M.R.C.P. in 1896. After some years in Jamaica he developed a huge general practice in Surbiton before moving up to 89 Harley Street. He weighed twenty stone, and his wife weighed six.

The other physicians saw their afternoon out-patients from 2 till about 4 o'clock. Gibbes' patients' cards were labelled 12 noon, and on Friday mornings the first out-patients began to arrive shortly after 8 o'clock. At 11 Gibbes would arrive. He had a cup of soup at 12 and a cup of tea and a diabetic biscuit at 3 o'clock, and would leave his room at 7, having seen about 200 out-patients. He was one of the three people I have known who never forgot a face and seldom a name. Most of his patients were chronic invalids, variously incapacitated, most of them with heart disease of one kind or another but some whom we would now call neurotic. They came back at intervals of about three months, and I now know that they regarded him as a kind of father figure to whom they could turn for advice and comfort. Once when I had influenza he came in to see me before 9 o'clock in the morning, and as he left he remarked that he had 16 patients in Harley Street that day, 8 of whom were G.A. cases. When I asked what this meant, he explained that these would be paid for by God Almighty: he had a special section in his ledger headed "G.A." and hoped to be paid in the next world, although he was worried by the contra account. When the war came, and I went to France, he used to write to me, and always prefaced his letters "Robert toi j'aime," which he said was a quotation from "Robert the Devil" and in every way suitable.

There were some great differences between the hospital then and now. First, the patients then sought advice and treatment directly: Lloyd George's 1911 Act was still new, and did not cater for wives and children, so few patients were referred by their family doctors. Secondly, there was no formal teaching, although a few doctors and students came occasionally. It is difficult to be precise about the level of the general fund of our knowledge at that time. Sir James Mackenzie was our prophet. We used his ink polygraph, but turned with relief to the electrocardiograph, which was easier to use, and, we thought, easier to interpret. We carefully and repeatedly recorded our three leads and never dreamt of twelve. We recognized the arrhythmias and compared the figures of the Riva-Rocci sphygmomanometer with those of the Pachon oscillometer. We were greatly concerned with the electrical axis of the heart, and I found myself trying to grasp trigonometrical symbols that I never really got friendly with.

We puzzled over the significance of inverted $T$ waves. Looking back, it seems odd that two years had elapsed since James B. Herrick wrote his paper on Sudden obstruction of the coronary arteries. I never heard the diagnosis of coronary thrombosis made in those days, but I saw many patients with angina pectoris. Most of our patients had, I think, rheumatic heart disease, and cardiac syphilis and aneurysm were common. Our treatment was, of course, narrower in its range. Cardiac surgery did not exist. Bacterial endocarditis or, as we then called it, malignant endocarditis was uniformly fatal within 12 months. Digitalis was principally used as the tincture or as Nativelle's granules. Potassium bromide was our tranquillizer, and paraldehyde, given orally, was extensively used for the insomnia of heart disease. Guy's pill was our usual diuretic. I never saw Southey's tubes used, but œdematous legs were punctured with a sterile needle and wrapped in absorbent dressings. We had a special cardiac bedstead for such sufferers. Our patients were not neglected. It cannot be said, I think, that they were "brought into hospital to lie and rot, and that masterly inactivity was the watchword." The hospital being so near Harley Street, the physicians could and did look in at unexpected times to see patients who were seriously ill. Curiously enough, I cannot remember any one of them missing any of his out-patient days or ever having to deputize in his absence; not did I ever hear one of them speak unkindly of a colleague, although they were really a group of individuals rather than a team.

They were well served by the Matron, Miss Maxwell Moffatt, and the nurses, who maintained a high standard of service for miserable pay. The Hospital income for 1914 was $£ 3509$ and the 
expenditure $£ 3473$ to cover everything. Salaries were not large, although devoted service was often given for them. The Secretary (Robert Whitney) was appointed in 1912 "at an annual salary of $£ 120$ and that he be requested to put forward a sum of $£ 250$ as a surety of his bona fides."

I have tried to tell you something of the men who built the barn and gathered the first ears of the amazing harvest that their successors reap in the vast field of cardiology. They were not saints, but simple, kindly men with a great sense of duty. An Indian mystic wrote: "To fly in the air is not a miracle, the meanest fly can do it; to cross rivers without bridges is not a miracle, the meanest dog can do it; but to care for suffering hearts is the work of holy men." Well, they cared for suffering hearts, and by their labours won the affection and gratitude of many. Their kindness is remembered by the Ulsterman who spent his tuppence. 